Print ISSN: 2288-4637 / Online ISSN 2288-4645

doi:10.13106/jafeb.2020.vol7.no11.1077

\title{
Economics During Global Recession: Sharia-Economics as a Post COVID-19 Agenda
}

\author{
Aryati ARFAH ${ }^{1}$, Fahruddin Zain OLILINGO ${ }^{2}$, S. SYAIFUDDIN ${ }^{3}$, D. DAHLIAH ${ }^{4}$, N. NURMIATI \\ Aditya Halim Perdana Kusuma PUTRA ${ }^{6}$
}

Received: August 01, 2020 Revised: September 30, 2020 Accepted: October 15, 2020

\begin{abstract}
This research is a literacy study regarding the implementation and management of the economic role of haria as a new strategy in overcoming the problem of the global financial crisis that has hit the middle of the COVID-19 pandemic. The research method comes from previous studies to compare the capitalist, socialist, and sharia economic systems. In response to various economic uncertainties, both internal and external, the ability to seize opportunities and transform has become the key to economic resilience. Islamic economics can be an alternative in responding to the dynamics of the global and national economy. Several things need to be taken into consideration in fulfilling the sharia economy and the primary strategy chosen must come from the inputs given by the stakeholders, including business actors, associations, regulators as well as experts, and academicians. The primary strategy in implementing the sharia economy also requires the support of various parties in order to develop sustainability. Strengthening regulation and governance is one of the fundamental factors. Optimization of the sharia economy based social sector such as Zakat, Infaq, Sadaqah, and Waqaf can be optimized both for collection and distribution so that the concept of sharing can certainly support the development and the economy both nationally and globally.
\end{abstract}

Keywords: Sharia Economics, Global Recession, Economic Systems

JEL Classification Code: B15, B24, B55, D31

\section{Introduction}

${ }^{1}$ First Author and Corresponding Author. Associate Professor, Department of Development Study, Faculty of Economic \& Business, Universitas Muslim Indonesia, Makassar, Indonesia [Postal Address: Urip Sumoharjo, Makassar city, South Sulawesi, 90231, Indonesia] Email: arfah.aryati.fekon79@gmail.com

${ }^{2}$ Associate Professor, Department of Economics Development Studies, Faculty of Economics, Universitas Negeri Gorontalo, Indonesia

${ }^{3}$ Associate Professor, Department of Islamic Economics, Faculty of Shariah and Islamic Economic, IAIN Ternate, Ternate, Indonesia

${ }^{4}$ Associate Professor, Department of Development Study, Faculty of Economic \& Business, Universitas Muslim Indonesia, Makassar, Indonesia

${ }^{5}$ Associate Professor, Department of Management, Faculty of Economic, Universitas Patria Artha, Makassar, Indonesia.

${ }^{6}$ Assistant Professor, Department of Management, Faculty of Economic \& Business, Universitas Muslim Indonesia, Makassar, Indonesia

() Copyright: The Author(s)

This is an Open Access article distributed under the terms of the Creative Commons Attribution Non-Commercial License (https://creativecommons.org/licenses/by-nc/4.0/) which permits unrestricted non-commercial use, distribution, and reproduction in any medium, provided the original work is properly cited.
The essence of Sharia economics, which positions justice and unity, is conveyed through the Islamic spirit, which is claimed to be the differentiator between economic systems that exist today or have existed on this earth. In contrast to economic schools such as capitalism, socialism, and mercantilism; Islamic economics strongly opposes the exploitation of profits on a large scale to the capitalists (both as creditors, and debtors) (Kuran, 1996; Pryor, 1985) which, in practice, forms an image of being rich among many poor people. The existence of the Islamic economy or Islamic economy that has existed for hundreds of years has been practiced and proven to provide benefits and benefits in the heyday of Islam in the past, the development of an increasingly modern era has finally replaced the position and essence of Islamic economics with the economic system designed by humans who think economics such as capitalism and socialism are ideal to accelerate the progress of human civilization in all sectors. However, in the long journey of human civilization, the economic systems such as capitalism, mercantilism, and socialism have proven to record many tragic financial histories for humankind. 
History records that no less than 4 (four) economic recessions occurred globally, namely in 1975, 1982, 1991, and 2009. For example, the global crisis in 1975 was triggered by the post-World War II energy crisis. The oil embargo on countries such as America, UK, Denmark, and so on started stagnation and over-rate inflation. Then the world economic recession in the 1980 s, to be precise between 1980 to 1983 was also triggered by a crisis in the supply of oil supplies from Middle Eastern countries so that countries such as America, Canada, West Germany, Italy, Britain, and Japan were forced to increase their interestrest to control inflation. The 1991 and 2009 crises' motive was triggered by the collapse in the financial, property, and economic sectors. The financial crisis has occurred since the 3 rd century to the 21 st century as it is now. Almost $98 \%$ of the crises started from countries adhering to the economy of capitalism and mercantilism, which had a domino effect globally on developing and developing countries.

In Indonesia itself, the crisis has also hit, namely, in the 1998 situation in the ASEAN region, which also had a severe impact on Indonesia, the banking and financial crises in 2008 and 2015. In 2020, the crisis has also hit the world as a result of the COVID-19 pandemic. Problems that initially attacked health ultimately caused a systemic impact on the social, economic, socio-economic, political, cultural, and defense orders (Al-Mansour \& Al-Ajmi, 2020; Khan et al., 2020; Khanthavit, 2020). The issue of the financial crisis caused by COVID-19 is said to be the worst ever in world history. It is a crisis which has affected all aspects of human civilization. Reflecting on this description, it is only fit to say that the world must change its economic order and structure, which is pro-justice and pro-togetherness, namely the Islamic economy based on sharia. The Islamic financial system is not a middle way between the capitalist, socialist and communist economic systems. The Islamic economy is independent; provides a long explanation of what can be traded or not and which law is following sharia or mubah. The purpose and essence of Islamic economics are harmonies to achieve Islam's goals and to be a blessing for the whole world.

Following the Qibla, Islamic economics is based on the Quran, where the guarantee of justice, prosperity, togetherness and family as a bridge between human beings (hablu-minannas), and the existence of devotion and worship to Allah SWT (hablu-minallah) is an absolute condition in the economic application of Islamic / Shariah economy. The simplest difference between the capitalist, socialist, and communist economic systems and the Sharia economic system is the interest system (rates) vs. the revenue sharing system (ratio). The main focus of Shariah economic implementation is the real sector, especially those that have the potential to increase economic growth nationally. More specifically chosen is goods production and the services sector. The purpose of this study is to make it as a reference as well as for critical review for economic policymakers and stakeholders regarding the urgency of implementing Islamic economics / Islamic economics as a new stream of financial strategies that are more stable and more humane. Of course, this study's ideas and concepts are based on Islamic principles that are as per the Sharia, are expected to be the best solutions to create a healthy economic order-starting from Indonesia for the world.

Apart from referring to the Quran and Sunnah in general, the target of Islamic economic development also refers to the state which protects the life of the people. It is used for the people's greatest prosperity with the principles of togetherness, just efficiency, sustainability, environmental awareness, independence, and maintaining a balance between progress and national economic unity. The aspiration to minimize inequality and discrepancy is the main target of sharia economic development (Alam et al., 2020; Alam, Tabash, et al., 2020). Therefore, to implement the Sharia economy as a new flow in the economy, apart from referring to the things mentioned above, efforts to realize the Islamic economy include: strengthening partnerships and institutional aspects, namely government, private, financial institutions and entrepreneurs through the implementation of the Islamic financial system. The regulations to improve the position of the Islamic economy in Indonesia as a national economic strategy. The global economy's challenges are increasingly complex and varied; This has become more pronounced not only since 1998, 2008, and 2015 crises. The world economic crisis caused by COVID-19 has opened our eyes, not only the Indonesian people but the whole world, to the crisis that affects all aspects of life. It can be argued that all forms of crisis throw trade, finance, and geopolitics into chaos, placing countries at risk of instability and vulnerability.

\section{Sharia, Capitalist, Socialist as Economic- Systems}

The economy is a combination of words that come from Greek, namely Oikos (family) and nomos (regulation/ management). The term was later adopted by the Church in 1440 to describe a government or administration system that was subsequently adopted by the state in the 19th century. However, the economic system's application has been around since humans have created, supplied, and distributed goods or services. Various models of the exchange system and the medium of exchange as an economic system also vary, from bartering, gold/silver/bronze, to using money to exchange goods and services. The definition and urgency of creating an economic system between sharia, socialist, and capitalist as part of a variety of economic systems are so that the design of governance and income distribution 
becomes more structured and patterned. Indeed, economics is generally defined as the study of human behavior in using resources to produce goods and services to meet human needs.

Before the existence of capitalism's economic system, mercantilism had long dominated the financial system in the middle ages, where the mercantilism system made the government defeat the trade sector for centuries so that instability in power domination caused economic inequality. The mercantilism system considers that all aspects of production, including land and agricultural land, are controlled by the state and the government. The practices of economic oligarchy, monopoly, and economic imperialism are visible patterns in the mercantilist economic system. Therefore, this criticism gave birth to many economic thinkers who thought that the bourgeoisie was an opportunist party. Economic thinkers criticized the financial system in the form of mercantilism as a form of injustice in the distribution of economy, wealth, and power. Adam Smith is one of the classical economic figures who opposed and criticized the mercantilist system; In Smith's thinking, the production movement in the economy views that the government only functions as a supervisor of the people's production process.

However, in practice, even though the capitalist economic system has been running until now, it is not uncommon for criticisms of the capitalist economic system to be encountered. In practice, the capitalist system has also produced various monopolistic and oligopoly practices. In line with this criticism, a revolutionary figure, Marx, initiated the revolutionary overthrow of the capitalist economic system into a socialist economic system. Marxism assumes that the capitalist system creates many inconsistencies and contradictions in its practice because of its irrational ways. It is added that the capitalist economic system prioritizes profits and capital accumulation on the social needs of society; workers are only a factor of production. They do not act as an essential factor in the core and necessary decisions of the companies. There is a difference between the capitalist and the socialist economies; the Islamic economic system in a noble way also aims to achieve the prosperity of the people, but the management system of the Sharia economic system or Islamic economy is identical to the implementation of Islamic values; namely equality, justice, and the balance that regulates the economic practices. Haram should be shunned. In brief, some forms of similarities and differences between the three economic systems are described in Table 1.

\section{Capitalist Making Us Grow-Up, and Making Falling Us Too}

It cannot be denied that economic progress has also stimulated other advances in human history; the limitations of exploration have made humans more continued to carry out production to meet their needs. The primary indicator of capitalists is maximizing capital through maximizing returns. On the one hand, the economic acceleration carried out by the capitalist system can be seen as a positive and fair side because it gives each of us full individual freedom to compete and enrich themselves through their potential so that they are considered to have a high side of justice. Although, at some level, the capitalist economic system is too pragmatic, individualistic, and selfish. In the history after the second world war, the global economic recession occurred four times; Also, in the history of human civilization there is a bad record about a pragmatic economic system; prioritizing groups and groups of capital owners have caused global economic recession since the 3rd century until present. In practice, the capitalist economy is inspired by the Laissez-Faire economic theory that existed in the 18th century. The implementation of Laissez-faire strongly opposes government intervention in business affairs. The government only acts as a supervisor of economic activity, and society is the driving force of the economy and competition. Although in the end, Laissezfaire was opposed in 1775 because it was considered to increase the potential for poverty and socio-economic inequality.

Currently, all the world leaders in the world are very busy looking for a way out to save the economy of their respective countries. The COVID-19 pandemic has brought the entire world into a recession without any exceptions. Small mistakes made either intentionally or unintentionally by large countries will trigger destructive economic impacts for other countries due to the capitalist economic system. In substance, the economic problems embraced by the dominant countries in the world that adhere to a capitalist economic system have reached the peak of the crisis long ago. Starting in 2009, which was triggered by Subprime Morgate in the US, then spread everywhere as well as the crisis of confidence in wall-street in the US and the bankruptcy of Lehman Brothers which took the floor on wall-street, which became a trigger that initially came from superpowers and investors in other countries. Investing-countries do not want to bear losses alone, the efforts made by governments with the power of capital is to increase the interest rates on their foreign debt loans to creditor countries by triggering the value of their country's currency rates to grow as well. As a result, developing countries will get affected by this system. Until developing countries and countries lagging behind will never experience a significant increase due to the capitalist economic system, they are trapped between economic growth that comes from loans with high-interest rates and as a result makes it difficult to settle the loan or debt. 
Table 1: Similarities and differences in economic systems

\begin{tabular}{|c|c|c|c|}
\hline & Capitalist & Socialist & Sharia \\
\hline Definition & $\begin{array}{l}\text { An economic understanding that } \\
\text { extends the process of obtaining } \\
\text { profits and the accumulation of } \\
\text { individual benefits }\end{array}$ & $\begin{array}{l}\text { Economic understanding that } \\
\text { gives everyone considerable } \\
\text { freedom to drive economic } \\
\text { activities with government } \\
\text { intervention }\end{array}$ & $\begin{array}{l}\text { Economic understanding which } \\
\text { studies the economic problems of } \\
\text { the society which are inspired by } \\
\text { the Islamic values }\end{array}$ \\
\hline $\begin{array}{l}\text { The role of } \\
\text { government }\end{array}$ & $\begin{array}{l}\text { Only as a superintendent of the } \\
\text { economy }\end{array}$ & Supervised by the government & $\begin{array}{l}\text { Referring to the Islamic religious } \\
\text { regulations, the government } \\
\text { supervises and manages }\end{array}$ \\
\hline \multirow{5}{*}{ Features } & $\begin{array}{l}\text { People choose the right of } \\
\text { authority in doing their economy }\end{array}$ & $\begin{array}{l}\text { The government regulates } \\
\text { economic activities }\end{array}$ & $\begin{array}{l}\text { Activities are regulated by the } \\
\text { community, monitored by the } \\
\text { government, both refer to the } \\
\text { Islamic religious regulations and } \\
\text { manage an even distribution of } \\
\text { income }\end{array}$ \\
\hline & $\begin{array}{l}\text { Production tools are in the hands } \\
\text { of individuals or corporations }\end{array}$ & $\begin{array}{l}\text { The state regulates the means of } \\
\text { production }\end{array}$ & $\begin{array}{l}\text { Production tools are regulated } \\
\text { by the state, supervised by the } \\
\text { government; both refer to Islamic } \\
\text { religious regulations }\end{array}$ \\
\hline & $\begin{array}{l}\text { There is free competition in the } \\
\text { market }\end{array}$ & $\begin{array}{l}\text { There is no free competition in the } \\
\text { market }\end{array}$ & $\begin{array}{l}\text { Free competition is allowed but is } \\
\text { still according to the prescribed } \\
\text { rules }\end{array}$ \\
\hline & $\begin{array}{l}\text { Innovation and production factors } \\
\text { are fully in the hands of the people } \\
\text { or the owners of capital }\end{array}$ & $\begin{array}{l}\text { The state controls the ownership } \\
\text { of production factors }\end{array}$ & $\begin{array}{l}\text { Innovation and production } \\
\text { factors are in society's hands, } \\
\text { the characteristic of property } \\
\text { ownership and income distribution } \\
\text { refers to the concept of Islam }\end{array}$ \\
\hline & Individualistic & Collectivism & Collectivism \\
\hline \multirow{5}{*}{ Positive side } & $\begin{array}{l}\text { Innovation and production can } \\
\text { sustain consumption and vice } \\
\text { versa }\end{array}$ & $\begin{array}{l}\text { Consumption is regulated based } \\
\text { on the amount of production, } \\
\text { which is also held }\end{array}$ & $\begin{array}{l}\text { The amount of production } \\
\text { determines the even distribution of } \\
\text { consumption }\end{array}$ \\
\hline & $\begin{array}{l}\text { Increase individual initiative and } \\
\text { creativity }\end{array}$ & $\begin{array}{l}\text { Increase the value of } \\
\text { togetherness }\end{array}$ & $\begin{array}{l}\text { Increase creativity and value } \\
\text { together }\end{array}$ \\
\hline & $\begin{array}{l}\text { Communities have freedom in } \\
\text { managing resources }\end{array}$ & $\begin{array}{l}\text { The community does not have } \\
\text { full freedom to own the available } \\
\text { economic resources }\end{array}$ & $\begin{array}{l}\text { People have the freedom to } \\
\text { manage resources according to } \\
\text { Islamic concepts and values }\end{array}$ \\
\hline & $\begin{array}{l}\text { Broad recognition of personal } \\
\text { rights }\end{array}$ & $\begin{array}{l}\text { Lack of full recognition of personal } \\
\text { rights }\end{array}$ & $\begin{array}{l}\text { The recognition of personal rights } \\
\text { has certain limitations }\end{array}$ \\
\hline & $\begin{array}{l}\text { Market mechanisms govern the } \\
\text { economy }\end{array}$ & $\begin{array}{l}\text { The role of government in } \\
\text { governing the economy }\end{array}$ & $\begin{array}{l}\text { Market mechanisms govern the } \\
\text { economy }\end{array}$ \\
\hline $\begin{array}{l}\text { Basic } \\
\text { principles }\end{array}$ & $\begin{array}{l}\text { Production and consumption and } \\
\text { individual property ownership, } \\
\text { income distribution }\end{array}$ & $\begin{array}{l}\text { The government determines } \\
\text { production and distribution }\end{array}$ & $\begin{array}{l}\text { Tawhid, brotherhood, morality, } \\
\text { productivity, equitable distribution } \\
\text { of income }\end{array}$ \\
\hline $\begin{array}{l}\text { Economic } \\
\text { profit system }\end{array}$ & $\begin{array}{l}\text { The interest rate is determined } \\
\text { by the owner of capital and the } \\
\text { market mechanism }\end{array}$ & $\begin{array}{l}\text { The government determines the } \\
\text { interest rate }\end{array}$ & Profit sharing and risk sharing \\
\hline
\end{tabular}


The beginning of the capitalist economic system was created like a horse pulling a carriage, accelerating economic growth and benefiting owners of capital. But like a horse pulling a chariot, the faster the horse goes, the more out of control the carriage will be so that the carriage will lose its way, crash and crash against the cliffs or rocks around it. The capitalist economic system is very thick with the terms inflation, banknotes, and banking. In 1971, with the aim to accelerate and develop the US economy, the US unilaterally took the decision under which the US dollar was not backed up or equalized to gold or silver anymore. Still, dollars were printed according to the US needs, since then, the dollar was just plain paper with no value. The capitalist economic theory itself explains that a large amount of money in circulation will trigger inflation, which is also large. Inflation will trigger a price increase triggered by an imbalance between price and aggregate demand in the market. This price increase will cause it to be difficult for most people to meet their needs; thus, unemployment and economic decline will occur. It should have been in the mirror before 1971 that any form of exchange was determined based on the measurement of the value of gold and silver like the Roman era.

\section{Sharia Economic as a New Wave Strategy}

Islam does not deny market power and economic competition; even the profit motive is acceptable but has specific rules and limitations. The fundamental difference between the capitalist economic system and the sharia economy or Islamic economy is that in secular capitalism, profit and private ownership are given uncontrolled rights and powers. It seems that anyone who can have full authority in terms of capital is the winner and determinant of the game. Even though they have boundaries, these limits are imposed by humans and can always change legislation; however, in the sharia economic system, regulations refer to things that have been outlined by Islamic religious principles. Imagine that if the rules are made and can be changed along with the development, then the system's modifier is, of course, the owner of the highest power or the owners of capital.

The definition of sharia is the rules and laws that have been outlined by Allah (Islam God) or which are outlined in the primary and imposed on humans, especially Muslims, to obey them (N. Alam \& Al-Amri, 2020). In certain studies, the sharia economy is not just an order but a worship of God. In practice, Islamic economics is a branch of science in economics that aims to realize human welfare through the allocation and distribution of scarce resources per Islamic teachings without limiting individual freedom, learning a sustainable macro, micro-economic and ecological balance (Tabash, 2019). Besides ending in destruction and detrimental to the wider community because of leaving injustice, this is high time that the capitalist system is replaced by a proven and stable sharia economic system. Sharia economic stability is fundamentally supported by five main pillars, including:

1. The use of free currency is determined by gold and silver because gold and silver are free from inflation, such as in ancient Rome, the use of gold and silver in the form of dinar and dirham was used as a reference medium of exchange.

2. Open markets (open markets). Not much different from the capitalist economic system, which also presents an open market for a free and competitive market environment. However, the practice demonstrated by the capitalist economy is that the capitalist economic system is very vulnerable to speculative actions in its journey. Open market system is not much different from the capitalist economic system, which also presents a free market as a perfect and open competitive environment. However, the practice demonstrated by the capitalist economy is that in its journey, the capitalist economic system is very vulnerable to speculative action. They were referring to the US government policy in 1971, which stated that the use of US dollars no longer relates to gold but instead is printed as per US interests. Speculative action can occur considering that more than $80 \%$ of countries in the world use the US dollar as a reference for the exchange rate of their country's currency, that is, when the US dollar contracts, it will trigger the currencies of other countries to experience depression. A speculative economy will only absorb a lot of money but only a little labor. Ironically, a speculative economy by holding money will affect the macro and micro economy in production and consumption.

3. Open distribution and logistic infrastructure. Where all people can become distributors without a monopoly, without the existence of a monopoly, especially capital, which refers to the use of gold as a medium of exchange; it will make prices more stable, aggregate demand, and consumption will find their equilibrium point on an ongoing basis.

4. Open production infrastructure, namely household production factors such as SMEs, accompanies extensive industrial infrastructure so that the problem of production scarcity and price games can be avoided, and there is no production monopoly.

5. Shirkah and Qirad. This means that both owners of capital and workers are equal in terms of decision making. Both parties bear all forms of loss and gain. In contrast to a capitalist economy where the practice of profit sharing seems unfair, even the tendency to loss-sharing is not visible. 
In line with the pillars of the sharia economy, the fundamental values in the sharia economic system or Islamic economy contain four things: first, ownership, where the aspect of ownership which includes profit, workforce, and business, as well as assets and assets, is also wholly owned by humans as managers and owners of assets, but in specific regulations, the amount of wealth, profit and business transactions is maximally attempted to donate or waqf (given to people, groups who are believed to be able to manage for the public interest). Regarding the ownership factor, the differences between a capitalist economy, a socialist economy, and a sharia economy are explained in Table 2; second, justice in doing business the principle of fairness does not mean that it must always be equal, but the fair in sharia economy represents ideals. The amount of profit and loss is borne jointly by both debtors and creditors, which is, of course, follows the agreement; Third, cooperation in kindness. Namely, cooperation is carried out together based on the spirit of helping in kindness. Including competition in doing business on the principles of assisting support, justice, and togetherness; fourth, balanced growth, which refers not only to balanced economic growth but also to the welfare that grows along with economic growth and environmental and ecological balance. Therefore Islamic economic values generally refer to the control of individual assets, income distribution, business optimization, financial transactions, social participation, and transactions of goods and services based on morality, decency, balance, civilization, and togetherness.

\subsection{Sharia Economic Mechanisms and Management}

Property ownership in the sharia economy is regulated following proper limits, meaning that property ownership is given full rights for a person. Still, it is not justified that the accumulation of assets, including property ownership, is not allowed to gain from the interest rate, derived from speculation, extortion, gambling, and all things that come from actions that violate aspects of morality. Property owners will be distributed inclusively to all lower-middleclass people through nisab (calculation) in zakat, infaq, and sadaqah. The Sharia economy upholds justice and emphasizes risk and profit-sharing. Freedom of exchange; freedom to choose a destination and business partners must be per the principles of sharia; intervene in the bidding process. The fair value of profits and losses is shared following the Sharia principles and the agreement of the two parties. Apart from that, financial transactions based on transactions in the real sector cannot carry out non-real transactions such as money trading.

Table 2: Comparison of Ownership Concepts: Capitalist, Socialist, Sharia

\begin{tabular}{|c|c|c|c|}
\hline Indicator & Capitalist & Socialist & Sharia \\
\hline $\begin{array}{l}\text { The nature of resource } \\
\text { ownership and output }\end{array}$ & $\begin{array}{l}\text { Absolute ownership by } \\
\text { individual humans }\end{array}$ & $\begin{array}{l}\text { The State or state authorities } \\
\text { represent absolute } \\
\text { ownership by humans. }\end{array}$ & $\begin{array}{l}\text { God is the absolute owner; } \\
\text { humans have the right to } \\
\text { have the limits set by God. }\end{array}$ \\
\hline Utilization Rights & Humans are free to use it & Humans are free to use it & $\begin{array}{l}\text { Utilization by humans follows } \\
\text { God's provisions }\end{array}$ \\
\hline Ownership Priority & $\begin{array}{l}\text { Individual property rights are } \\
\text { respected }\end{array}$ & $\begin{array}{l}\text { Public property rights are } \\
\text { respected }\end{array}$ & Individual, Public and State \\
\hline $\begin{array}{l}\text { The role of the individual and } \\
\text { the state }\end{array}$ & $\begin{array}{l}\text { Individuals are free to use } \\
\text { resources }\end{array}$ & $\begin{array}{l}\text { The state has the authority to } \\
\text { regulate the use of resources }\end{array}$ & $\begin{array}{l}\text { There are proportional } \\
\text { obligations of individuals, } \\
\text { society and the state }\end{array}$ \\
\hline $\begin{array}{l}\text { Distribution of ownership and } \\
\text { ownership of resources and } \\
\text { outputs }\end{array}$ & Rely on market mechanisms & Rests on the role of the state & $\begin{array}{l}\text { Markets, government, and } \\
\text { society by following the rules } \\
\text { of the Quran }\end{array}$ \\
\hline Responsibility and utilization & $\begin{array}{l}\text { Responsibility to yourself } \\
\text { economically and technically }\end{array}$ & $\begin{array}{l}\text { Accountability to the public } \\
\text { economically and technically }\end{array}$ & $\begin{array}{l}\text { Responsibility to personal, } \\
\text { Public and God }\end{array}$ \\
\hline $\begin{array}{l}\text { Examples of adherent } \\
\text { countries }\end{array}$ & $\begin{array}{l}\text { US, Canada and some other } \\
\text { Western European countries }\end{array}$ & $\begin{array}{l}\text { China, North Korea, Syria, } \\
\text { Bolivia, India, Bangladesh, } \\
\text { Sri Lanka, Vietnam }\end{array}$ & $\begin{array}{l}\text { Saudi Arabia, Malaysia, } \\
\text { UAE, Arabia, Kuwait, Qatar, } \\
\text { Turkey, Indonesia, Bahrain }\end{array}$ \\
\hline
\end{tabular}


To realize the various objectives of economic policies, the role of the government's role is necessary as an agent in building and developing market mechanisms to maintain the efficiency and sustainability of resources to avoid damage to market mechanisms. In the sharia economic mechanism, it is also known as fiscal policy and monetary policy. Emphasis on fiscal and monetary policies also refers to the concepts of justice and equality, economic welfare, economic growth based on morality, and even income distribution. However, what is interesting in the sharia economic system is the existence of institutions zakat where zakat is an excess of costs that must be spent when the amount of assets has reached its maximum value. The zakat has different dosages depending on the ownership of assets or wealth. Zakat itself is regulated in the Islamic religious life guidelines, covering all aspects (e.g., agricultural products, mining, property, income) and so on, where the gold price determines the value of zakat. There are two types of groups related to zakat in its implementation, namely recipient's zakat and zakat givers. The recipient group is included in the poor, although broadly speaking, all Muslims can be recipients and givers of zakat. Apart from zakat, the process of income distribution chain without calculation is also known as infaq, sadaqah, and waqaf, namely several assets/profits /excess income issued based on the nature of generosity, which aims to help fellow humans.

The basic rules in sharia economic management must be free from the elements of gambling (masyir), uncertainty in buying and selling agreements or business affairs (Gharar), and interest-rates (usury), buying and selling transactions to something that is prohibited according to Islamic sharia, as well as the prohibition of speculative transactions. In the sharia economy, business contracts and buying and selling agreements are sacred because they must be transparent, bound by the Islamic law, and share profits and losses.

\subsection{Implementation of Economy Sharia}

Studies conducted by Alnori \& Alqahtani (2019) regarding the acceleration of the capital structure that compares companies engaged in non-financial fields with the concept of conventional and sharia companies in Saudi Arabia. By examining several variables on the financial capital structure (e.g., market leverage, book leverage, profitability, firm size, firm growth opportunities, assets, earnings); Alnori \& Alqahtani (2019) found that sharia compliance plays a significant role in decision making and acceleration in capital structure interventions. Alnori \& Alqahtani also emphasized that policymakers, bankers, and organizations' function is the spearhead for the sharia system to apply comprehensively. Next, Biancone \& Radwan (2018) With the theme of research on sharia-based financial complaints on public infrastructure projects with the object of state studies (e.g., UAE, India, Pakistan, Abu Dhabi, Saudi, Malaysia, Kuwait, Qatar,
Brunei) states that there are positive opportunities regarding financial-compliant on public subjects utility infrastructure due to consistent Islamic financial principles. Next, Elamer et al (2019) in his study explaining the impact of the Sharia Supervisory Board (SSB) on 63 banks in the UAE, Middle East, and North Africa countries also confirmed the results of research from Alnori \& Alqahtani (2019) The supervisory board structure and governance mechanisms can be realized by utilizing a sharia economy. Important notes underlined by Alnori \& Alqahtani (2019) and (Elamer et al., 2019) It is the government's role as policy-makers and regulators, which is needed to implement sharia economics inclusively. In the E-commerce sector, one of the studies from Ribadu \& Wan (2019) They concerned the sharia economy in transactions on the online marketplace by targeting the optimization of Sharia compliance e-commerce trust, emphasizing aspects of religious commitment based on Islamic law contracts, genuine honesty in products and business transaction processes, and involving third-party assurance presenting propositions through a collection of scientific literacy that these factors can increase the value of consumer confidence.

\subsection{Discussion: Opportunities and Challenges}

The scope of implementation and development of the sharia economy, which still leans towards the conventional financial sector, is also an obstacle why sharia-based economies are so challenging to find a proper place (Barata, 2019). The challenges in implementing the sharia economy are also very complicated; an essential thing is because this economic system comes from Islam. Islamophobia has become an issue that will become a significant stepping stone, especially for secular and liberal countries. Conceptually, we do not lead the opinion of readers and the world community regarding issues of Islam. However, it cannot be denied that the sharia economy itself is inherent and becomes a guide for economic life according to the guidance of Islam. In line with that, this article is one of the many empirical studies that compares the concept of a capitalist economy and a sharia economy. Almost all research conclusions conclude positive things about the application of the sharia economy, even though all research subjects come from countries with Muslim populations. As a form of opportunity, why the development of Islamic finance can be a new alternative, which is triggered by several factors including the urgent need in society for a financial system that is free from usury (interest-rate) such as conventional/capitalist finance (Noorzoy, 1982; Prasetya, 2015). Then, responsive regulations are related to the needs of Islamic finance and a model for developing the Islamic financial system that is already available globally for replication (Arafah \& Nugroho, 2016) so that this becomes the strength side to implement the sharia economy as an inclusive economic strategy 
The challenge then is also faced in the migration-system from a capitalist economy to a sharia economy, which does take a long time. Economic system migration is not easy considering the supply chain, value chain, and trade-chain between countries and requires a comprehensive agreement and understanding. COVID-19, which has made an impact on the global economic recession, should make economists and policymakers see the realities of the capitalist economy, whether it is still relevant or not to be used as a world financial flow collectively. As a country with the immense Muslim majority in the world, Indonesia cannot be separated from the problems of implementing the sharia economy as a companion to the capitalist economy that has existed since 75 years of independence. As a solution so that the paradigm of Indonesian society and its culture slowly changes, it separates conventional and sharia banking institutions.

Suppose previously in Indonesia; traditional banking institutions made sharia banking institutions as the company's new branch. In that case, this does not automatically increase the popularity of sharia banking amid the Muslim population's domination in Indonesia. Therefore, the government's tactical step is to make regulations to separate conventional and sharia banking institutions. Sharia banking in Indonesia then stands alone with the existing authorities accompanying conventional banking; the results turned out to be significant. COVID-19 in the records of financial institutions in Indonesia has made a positive note, meaning that the global economic recession that has hit the entire capitalist economic system in the world, including in Indonesia, has not had an impact on sharia financial institutions in Indonesia and has made the sharia financial sector in Indonesia remain stable and grow. The sharia economy has a significant impact on countries with Muslim populations such as the UAE, Middle-East, and several countries with a large Muslim majority problem, such as Malaysia, Brunei, and Indonesia. However, that does not mean that it cannot have a positive impact on non-Muslim countries. The increase in the world's Muslim population, which has experienced significant growth (e.g., France, America, England, and so on), can be an opportunity for the world, considering that Halal-Tourism as part of the income cycle is also still a hot issue discussed among management experts (e.g.,Shinsuke, 2014). Liberal and secular countries can use Halal-tourism and halal products as part of increasing GDP.

\section{Conclusion}

In response to the various economic uncertainties, both internal and external, the ability to seize opportunities and transform is the key to economic resilience. Islamic economics can present an alternative in response to the dynamics of the global and national economy. Various countries, especially Islamic countries, are competing to develop and implement a sharia economy that continues to grow along with the growth of the world's Muslim population, accompanied by increased awareness of halal products. The competition of Muslim countries also provides opportunities for secular and liberal states to take advantage of this. The capitalist economic phase that has been carried out by the world is bringing us to a terrible collision. So why not try to transform and implement the sharia economy as an alternative economic system? Indeed, secular and liberal countries are mostly determinants of the game of economy and production, but Islamic countries are almost a source of energy supply countries; plus, the Muslim population, which continues to experience an increase in population, means the same for increased consumption.

Several things need to be considered in fulfilling the sharia economy, namely that the primary strategy chosen must come from input from stakeholders, including business actors, associations, regulators, and experts, and academics. Not only that, but the primary strategy in implementing the sharia economy also requires the support of various parties to continue to develop sustainably. A basic strategy is needed to ensure a solid Islamic economic foundation. Strengthening regulation and governance is one of the fundamental factors. In addition to developing research and development capacity, increasing the quality and quantity of human resources, increasing public awareness, and literacy, and data, information, and technology are aspects that cannot be ruled out. Optimization of the sharia-based social sector such as Zakat, Infaq, Sadaqah, and Waqaf can be optimized for collection and distribution so that the concept of sharing can certainly support the development and the economy both nationally and globally.

\section{References}

Al-Mansour, J. F., \& Al-Ajmi, S. A. (2020). Coronavirus 'COVID-19': Supply Chain Disruption and Implications for Strategy, Economy, and Management. Journal of Asian Finance, Economics and Business, 7(9), 659-672. https://doi. org/10.13106/jafeb.2020.vol7.no9.659

Alam, M. K., Mustafa, H., Uddin, M. S., Islam, M. J., Mohua, M. J., \& Hassan, M. F. (2020). Problems of Shariah Governance Framework and Different Bodies: An Empirical Investigation of Islamic Banks in Bangladesh. Journal of Asian Finance, Economics and Business, 7(3), 265-276. https://doi. org/10.13106/jafeb.2020.vol7.no3.265

Alam, M. K., Tabash, M. I., Thakur, O. A., Sahabuddin, M., Hosen, S., \& Hassan, M. F. (2020). A Central Shariah Regulatory Authority for the Islamic Banks in Bangladesh: Legalization or Formation. Journal of Asian Finance, Economics and Business, 7(1), 91-100. https://doi.org/10.13106/jafeb.2020.vol7.no1.91

Alam, N., \& Al-Amri, H. A. (2020). Service Quality Perception and Customer Satisfaction in Islamic Banks of Oman. Journal 
of Asian Finance, Economics and Business, 7(9), 499-504. https://doi.org/10.13106/jafeb.2020.vol7.no9.499

Alnori, F., \& Alqahtani, F. (2019). Capital structure and speed of adjustment in non-financial firms: Does sharia compliance matter? Evidence from Saudi Arabia. Emerging Markets Review, 39(March), 50-67. https://doi.org/10.1016/j.ememar. 2019.03.008

Arafah, W., \& Nugroho, L. (2016). Maqhashid sharia in clean water financing business model at Islamic bank. International Journal of Business and Management Invention, 5(2), 22-32.

Barata, A. (2019). Strengthening national economic growth and equitable income through sharia digital economy in Indonesia. Journal of Islamic Monetary Economics and Finance, 5(1), 145-168.

Biancone, Pietro, P., \& Radwan, M. (2018). Sharia-Compliant financing for public utility infrastructure. Utilities Policy, 52(September 2016), 88-94. https://doi.org/10.1016/j. jup.2018.03.006

Elamer, A. A., Ntim, C. G., Abdou, H. A., \& Pyke, C. (2019). Sharia supervisory boards, governance structures and operational risk disclosures: Evidence from Islamic banks in MENA countries. Global Finance Journal, August 2018, 100488. https://doi. org/10.1016/j.gfj.2019.100488

Khan, K., Zhao, H., Zhang, H., Yang, H., Shah, M. H., \& Jahanger, A. (2020). The Impact of COVID-19 Pandemic on Stock Markets: An Empirical Analysis of World Major Stock Indices. Journal of Asian Finance, Economics and Business, 7(7), 463-474. https://doi.org/10.13106/jafeb.2020.vol7.no7.463
Khanthavit, A. (2020). Foreign Investors' Abnormal Trading Behavior in the Time of COVID-19. Journal of Asian Finance, Economics and Business, 7(9), 63-74. https://doi.org/10.13106/ jafeb.2020.vol7.no9.063

Kuran, T. (1996). The discontents of Islamic economic morality. The American Economic Review, 86(2), 438-442.

Noorzoy, M. S. (1982). Islamic laws on riba (interest) and their economic implications. International Journal of Middle East Studies, 14(1), 3-17.

Prasetya, Y. S. (2015). Riba and the injustice of the economic system of capitalism: A theoretical study. EKSYAR: Jurnal Ekonomi Syari'ah \& Bisnis Islam, 2(2), 472-493.

Pryor, F. L. (1985). The Islamic economic system. Journal of Comparative Economics, 9(2), 197-223.

Ribadu, M. B., \& Wan, W. N. (2019). An integrated approach towards Sharia compliance E-commerce trust. Applied Computing and Informatics, 15(1), 1-6. https://doi.org/10.1016/ j.aci.2017.09.002

Shinsuke, N. (2014). Resuscitation of the antique economic system or novel sustainable system? Revitalization of the traditional islamic economic institutions (waqf and zakat) in the postmodern era. Kyoto Bulletin of Islamic Area Studies, 7, 3-19.

Tabash, M. I. (2019). An Empirical Investigation on the Relation between Disclosure and Financial Performance of Islamic Banks in the United Arab Emirates. Journal of Asian Finance, Economics and Business, 6(4), 27-35. https://doi.org/10.13106/ jafeb.2019.vol6.no4.27 